\section{Improved Detection of Petunia Vein Clearing Caulimovirus}

\author{
M. Zeidan \\ The Plant Protection and Inspection Services, Ministry of Agriculture, Bet \\ Dagan 50250, Israel
}

\author{
Noga Sikron, J. Cohen, and A. Gera ${ }^{1}$ \\ Department of Virology, Agricultural Research Organization, The Volcani \\ Center, Box 6, Bet Dagan 50250, Israel
}

Additional index words. Petunia $\times$ hybrida, immuno-specific electron microscopy, polymerase chain reaction

\begin{abstract}
Petunia vein clearing virus (PVCV), a possible member of the caulimovirus group, was detected in several cultivars of vegetatively propagated petunias (Petunia Xhybrida Hort. Volm.-Andr.) grown in commercial nurseries. Leaf dip preparations and ultrathin sections of leaf tissue were analyzed by transmission electron microscopy (TEM). Spherical virus particles, $45-50 \mathbf{~ n m}$ in diameter, were observed in samples taken from symptomatic petunia plants. The virus was purified and a polyclonal antiserum was prepared. In immuno-specific electron microscopy (ISEM), the PVCV antiserum-treated samples reacted with a distinct decoration on the virus suspect particles. A polymerase chain reaction (PCR)-based assay was used to detect PVCV in total nucleic acid extracts derived from infected petunia plants. Two primer pairs were designed to flank a 736-basepair sequence located in the RNA-dependent RNA polymerase gene of the PVCV genome. A DNA fragment of predicted size was visualized in agarose gels. The authenticity of the amplified DNA fragment was confirmed by restriction analysis and by hybridization with the virus-specific PVCV DNA probe. The virus could be detected efficiently in high dilutions of sap extracted from infected petunia plants.
\end{abstract}

The introduction of new, vegetatively propagated, hybrid cultivars of petunia has led to the epidemic spread and accumulation of virus infections (Lesemann, 1996; Sikron et al., 1995). Eleven viruses have been detected in naturally infected petunia, often in mixed infections (Klinkowski, 1968; Sikron et al., 1995). Infections have been reported from all countries where vegetatively propagated petunias are cultivated (Bellardi et al., 1996; Lesemann, 1996; Sikron et al., 1995, 1999).

Petunia vein clearing virus (PVCV), a possible caulimovirus (Hull, 1984), has been detected in Germany (Lesemann and Casper, 1973), and recently in the United States (Lockhart and Lesemann, 1997) and Israel (Gera et al., 1999). The virus was shown to be carried through the germline of its host (Petunia sp.) to a high proportion of the next generation (Richert, 1992). Recently, PVCV was shown to have some features of retroelements

\footnotetext{
Received for publication 27 Dec. 1999. Accepted for publication 30 Mar. 2000. Contribution from the Inst. of Plant Protection, Agricultural Research Organization, The Volcani Center, Bet Dagan, Israel. No. 531/99. This work was supported by the Israel Flower Board and the Danziger "Dan Flower Farm." The cost of publishing this paper was defrayed in part by the payment of page charges. Under postal regulations, this paper therefore must be hereby marked advertisement solely to indicate this fact. ${ }^{1}$ To whom reprint requests should be addressed. Telephone: 972-3-9683571; fax: 972-3-9604180; e-mail: abedg@netvision.net.il
}

(Richert-Poggeler and Shepherd, 1997). Virus problems had not been experienced previously with petunia grown exclusively from seed. Vegetatively propagated petunias were recently introduced into the flower market (Weidner, 1994). The plant is becoming very popular in the European flower markets. Since petunia is mostly propagated vegetatively in Israel and Europe, the production of virus-free propagation stock is an important component of virus control. Therefore, suitable and sensitive virus-indexing methods must be established and made available for nurseries and plant protection authorities to ensure production of virus-free petunias. Electron microscopy (EM) techniques enable the detection of PVCV in plant tissue. However, we have experienced inconsistent results with EM, which have led to false-negative results, because of the low virus concentration and uneven distribution within the plants (Sikron et al., 1995). During EM indexing for PVCV of propagation material from commercial nurseries, plants initially indexed as negative were found to be positive in subsequent tests. Since the polymerase chain reaction (PCR) for DNA amplification has been successfully adapted for the detection of DNA viruses (Navot et al., 1992; Rybicki and Hughes, 1990), it would be advantageous to detect PVCV by PCR because of the test's high sensitivity and specificity. We describe here the detection of PVCV virions using EM and the amplification of the viral DNA fragments from total DNA extracts of infected petunia by the use of PCR, and compare the efficiencies of the two techniques.
Plant maintenance and inoculation. Various cultivars of petunia, with vein clearing symptoms, were collected from propagation nurseries in various parts of Israel. Infection with PVCV was confirmed using EM. Plants were transferred to a controlled-temperature greenhouse at $23 \pm 3{ }^{\circ} \mathrm{C}$ with supplementary lighting providing a 14-h photoperiod.

Virus purification. Petunia plants $\mathrm{cv}$. Chaplin grown at $23 \pm 3{ }^{\circ} \mathrm{C}$, showing strong vein clearing symptoms, were tested for the common viruses infecting petunia [tobacco mosaic virus (TMV), cucumber mosaic virus (CMV), potato virus $\mathrm{Y}$, and alfalfa mosaic virus], using enzyme-linked immunosorbent assay (ELISA) and EM. Plants confirmed positive for PVCV infection were selected for virus purification. Fresh leaves were ground in an Omni-mixer (Sorval Inc., Newtown, Conn.) for $3 \mathrm{~min}$ in $0.5 \mathrm{M}$ phosphate buffer, $\mathrm{pH} 7.0$, containing $0.75 \%$ sodium sulfite. Urea $(1 \mathrm{M})$ and $2.5 \%(\mathrm{v} / \mathrm{v})$ Triton X-100 were added and the homogenate was stirred overnight. The mixture was then filtered through gauze and centrifuged for $10 \mathrm{~min}$ at $5000 \mathrm{~g}_{\mathrm{n}}$. The aqueous phase was collected, layered over a $30 \%$ sucrose cushion, and centrifuged for $3 \mathrm{~h}$ at 95,000 $g_{\mathrm{n}}$ with a Beckman Type 35 rotor (Beckman, Palo Alto, Calif.). The pellet was washed carefully with double-distilled water and resuspended in $5 \mathrm{~mL}$ of $0.1 \mathrm{~m}$ sodium phosphate buffer, $\mathrm{pH} 7.0$, containing $1 \mathrm{~m}$ urea and $2.5 \%$ Triton X-100; it was stored overnight (12 h) at $4{ }^{\circ} \mathrm{C}$ and centrifuged for $10 \mathrm{~min}$ at $6000 \mathrm{~g}_{\mathrm{n}}$. The supernatant was layered over a sucrose gradient and centrifuged at $78,000 g_{\mathrm{n}}$ for $2 \mathrm{~h}$ at $8^{\circ} \mathrm{C}$ with a Beckman SW 28 rotor. The gradient columns were fractionated into $1-\mathrm{mL}$ fractions with the aid of a peristaltic pump, and the fractions were checked by EM. Fractions containing the highest concentrations of virus were pooled, diluted with five volumes of 0.1 M sodium phosphate buffer, $\mathrm{pH} 7$, and centrifuged at $139,000 g_{\mathrm{n}}$ for 90 min with a Beckman 65 Ti rotor. The resulting pellet was dissolved in $1 \mathrm{~mL}$ of $100 \mathrm{~mm}$ sodium phosphate buffer, $\mathrm{pH} 7$, and stored at $-80^{\circ} \mathrm{C}$.

Electron microscopy. Crude plant extracts in $0.1 \mathrm{~m}$ phosphate buffer or virus preparations were negatively stained with $1 \%$ uranyl acetate and examined for virus using a JEOL 100CX II electron microscope (Joel Ltd., Tokyo). For ultrathin sections, segments $(2 \times 1$ $\mathrm{mm}$ ) excised from young leaves of petunia that expressed symptoms of PVCV infection were fixed in $4 \%$ glutaraldehyde buffered with $75 \mathrm{~mm}$ potassium phosphate, $\mathrm{pH} 7$, for $2 \mathrm{~h}$. Noninfected control leaves were prepared similarly. The samples were then rinsed in buffer and postfixed in $2 \% \mathrm{OsO}_{4}$ for $3 \mathrm{~h}$. After a water rinse, the samples were dehydrated in a graded acetone series, embedded in an Epon-Araldite resin mixture (Agar Scientific Ltd., Essex, U.K.), and polymerized. Sectioned material was stained with aqueous uranyl acetate and lead nitrate. Immuno-specific electron microscopy (ISEM) decoration tests were conducted as described by Milne and Luisoni (1975).

Serology. Purified virus preparations $(\approx 0.1$ 
$\mathrm{mg} \cdot \mathrm{mL}^{-1}$ ) were emulsified with an equal volume of Freund's incomplete adjuvant and injected intramuscularly into both hip muscles of a 6-week-old female New Zealand white rabbit. Injections were repeated weekly for 4 weeks, and serum was collected weekly starting 2 weeks after the second injection (Zeidan et al., 1998). The specificity of the antiserum was tested by (ISEM) decoration (Milne and Luisoni, 1975).

DNA extraction. Genomic DNA was isolated from naturally infected petunia leaves according to Rogers and Bendich (1).

Amplification of PVCVDNA using the polymerase chain reaction. PVCV DNA fragments were amplified using the following pair of primers (10 pM each) deduced from the nucleotide (nt) sequence of the PVCV genome by Richert-Poggeler and Shepherd (1997) (Accession No. U95208). Sense primer (PV1) 5'-GAGGTCAGAGCAAGTCAGAGG-3' (nt 4339-4359) and antisense (PV-2) 5'GTAATGATTTGACTTGTTGAG-3' (nt 5055-5075) were purchased from Biotechnology General, Rehovot, Israel. The primers were designed to amplify a 736-bp fragment from PVCV DNA. Each reaction contained $100 \mathrm{ng}$ of DNA template $(2 \mu \mathrm{L})$, virus-specific primers (10 pM), $0.25 \mathrm{~mm} \mathrm{dNTPs}, 5 \mu \mathrm{L}$ of $10 \mathrm{X}$ reaction buffer: $100 \mathrm{~mm}$ Tris- $\mathrm{HCl}, 15 \mathrm{~mm}$ $\mathrm{MgCl}_{2}, 500 \mathrm{~mm} \mathrm{KCl}, \mathrm{pH} 8.8$, and one unit of Taq DNA polymerase (Boehringer Mannheim GmbH., Mannheim, Germany). The total volume was brought to $50 \mu \mathrm{L}$ with distilled water. The reaction mixture was overlayed with 50 $\mu \mathrm{L}$ of mineral oil and incubated in a thermocycler (Hybaid, Hybaid Ltd., Teddingtom, U.K.) according to the following protocol: 3 min at $95^{\circ} \mathrm{C}$; then five cycles of $95^{\circ} \mathrm{C}$ for 30 $\mathrm{s}, 60^{\circ} \mathrm{C}$ for $2 \mathrm{~min}$, and $72{ }^{\circ} \mathrm{C}$ for $2 \mathrm{~min}$; five cycles of $95^{\circ} \mathrm{C}$ for $30 \mathrm{~s}, 58^{\circ} \mathrm{C}$ for $2 \mathrm{~min}$, and $72{ }^{\circ} \mathrm{C}$ for $2 \mathrm{~min} ; 30$ cycles of $95^{\circ} \mathrm{C}$ for $30 \mathrm{~s}, 55$ ${ }^{\circ} \mathrm{C}$ for $2 \mathrm{~min}$, and $72^{\circ} \mathrm{C}$ for $2 \mathrm{~min}$; and, finally, $30 \mathrm{~min}$ at $72{ }^{\circ} \mathrm{C}$.

Amplified samples were subjected to electrophoresis in a $1.2 \%$ agarose gel, stained with $0.5 \mu \mathrm{g} \cdot \mathrm{mL}^{-1}$ ethidium bromide, and photographed under UV illumination (Sambrook et al., 1989).

Cloning of PVCV PCR product. The PCR product, $\approx 730 \mathrm{bp}$ in size, was excised from the gel, cleaned (Geneclean Kit, B1O 101, Vista, Calif.), and ligated to T/A pGEM vector following the manufacturer's protocol (Promega, Madison, Wis.). After transformation to DH $5 \alpha$ competent cells, white colonies were picked and plasmid DNA was prepared. The PVCV cloning was confirmed by restriction analysis of several clones, with BsmI restriction enzyme. One of the clones was radiolabeled and used for further analysis.

Radiolabeling of PVCV DNA. A 25-ng sample of plasmid DNA harboring PVCV sequences was subjected to radiolabeling with $\mathrm{a}^{32} \mathrm{P}-\mathrm{dCTP}\left(3000 \mathrm{Ci} \cdot \mathrm{mm}^{-1} ; 10 \mathrm{mCi} \cdot \mathrm{mL}^{-1}\right)$ by means of a random priming system, according to the manufacturer's protocol (random primer DNA labeling kit, Boehringer Mannheim, Germany).

Southern hybridization. Total nucleic acids $(0.5 \mu \mathrm{g})$ were extracted from petunia leaves
(250 mg fresh weight) and PVCV DNA was amplified. The PCR product was collected, subjected to electrophoresis, transferred to Hybond N+ (Amersham, Amersham Life Science Ltd., Buckinghamshire, U.K.) by the alkaline blotting method, and hybridized with the virus-specific PVCV DNA probe (Sambrook et al., 1989).

\section{Results and Discussion}

The symptoms of PVCV infection in cv. Chaplin are stunted young shoots, leaf yellowing, and severe vein clearing (Fig. 1). In the nursery, symptoms were most frequently expressed during the summer when temperatures were above $25^{\circ} \mathrm{C}$. When petunia plants

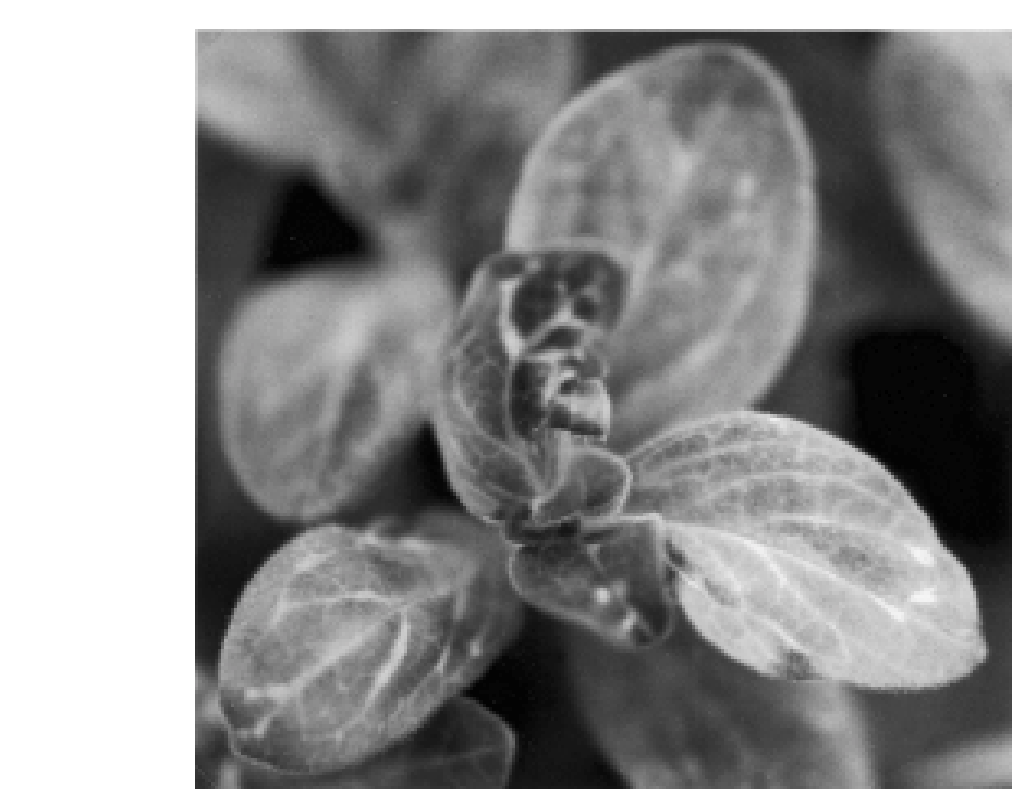

Fig. 1. Symptoms of leaf yellowing and severe vein clearing on leaves of Petunia cv. Chaplin naturally

infected with petunia vein clearing virus (PVCV).

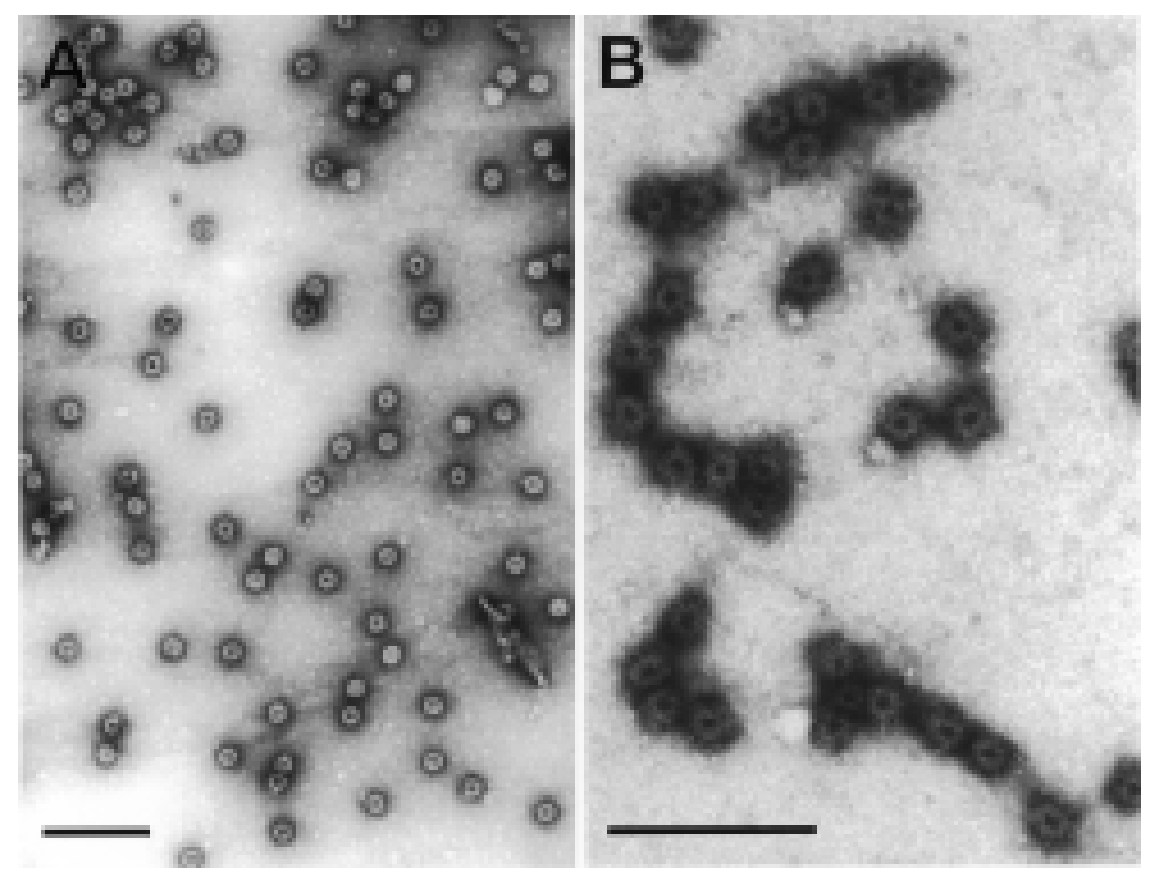

Fig. 2. Electron micrograph of purified petunia vein clearing virus (PVCV) particles stained with (A) uranyl

acetate and decorated with (B) specific antiserum. Bar $=0.25 \mathrm{~mm}$.

with mild symptoms were subjected to $25^{\circ} \mathrm{C}$ for a week, symptom expression was enhanced. The virus incidence within cv. Chaplin was $40 \%$ to $60 \%$, based on symptoms observed in the nursery (data not shown). Symptoms were occasionally observed within the cvs. Big Spark, Blue Spark, Bright Dream, Casablanca, Cascadias Pink, Cascadias Red, Cascadias Yellow Eye, Champagne, Charisma, Charme, Cherie, Chipper, Choice, Choppy, Happy Dream, Pink Spark, and Sweet Dream.

Electron microscopy. Analysis of PVCVinfected tissue with EM demonstrated the presence of spherical particles, $40-50 \mathrm{~nm}$ in diameter, which could be detected in crude extracts only when the plants expressed distinct symptoms. Analysis by EM for PVCV virions on 


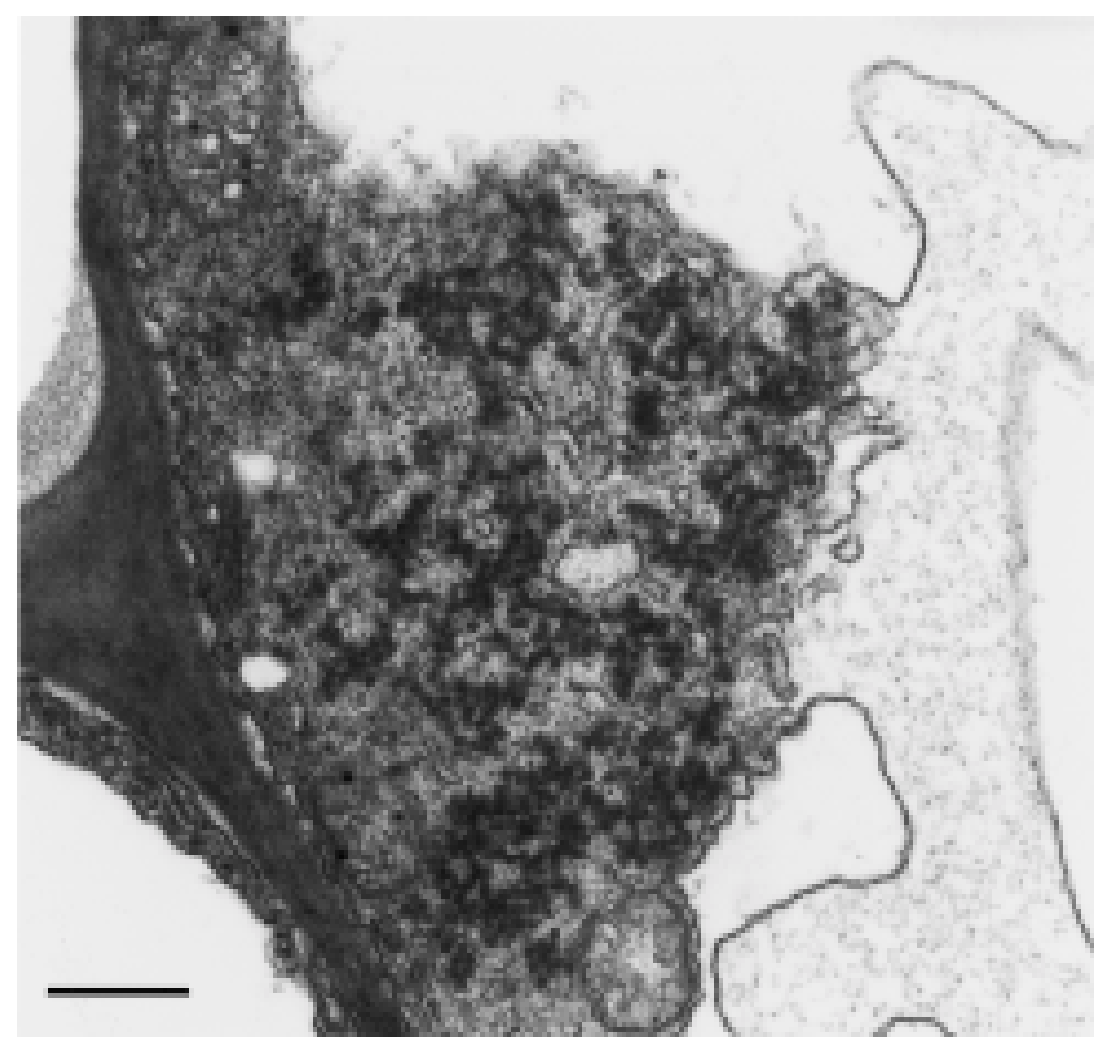

Fig. 3. Ultrathin section of petunia leaf cells showing particles of petunia vein clearing virus (PVCV) in the cytoplasm of parenchyma cells (particles are indicated by arrows). Bars $=0.5 \mathrm{~mm}$.

symptomless petunia leaves from infected plants was negative. In purified virus preparations, numerous spherical particles, similar in structure and size to those found in leaf dip preparations, were always observed (Fig. 2A). In immuno-specific electron microscopy, the specific antiserum produced against the virus particles resulted in a distinct decoration with

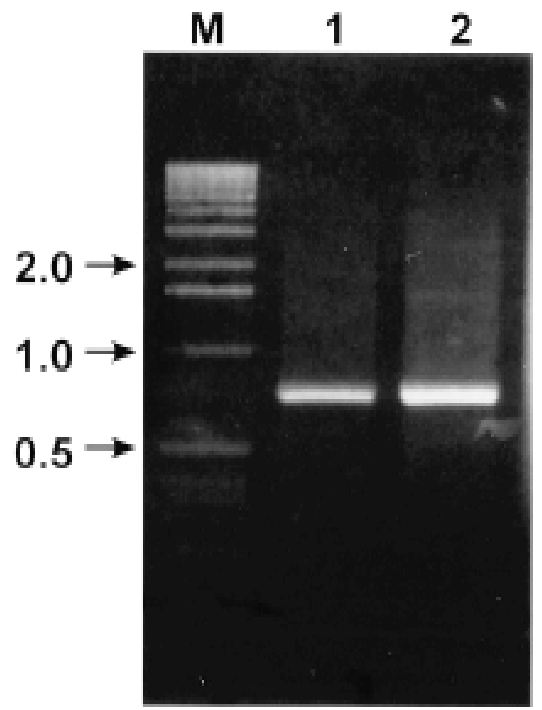

Fig. 4. Agarose gel electrophoresis of polymerase chain reaction (PCR) amplified petunia vein clearing virus (PVCV) DNA from graft-inoculated Petunia hybrida (lane 1) and naturally infected Petunia cv. Chaplin (lane 2), using primers PV1 and PV2. Lane M: DNA size markers (bp). the purified virus (Fig. 2B). Similar results were obtained when PVCV antiserum (provided by D. Lesemann, Biologische Bundesanstalt, Braunschweig, Germany) was used (results not shown). EM studies with ultrathin sections of infected petunia leaves revealed the presence of isometric particles scattered in the cytoplasm of infected paren- chyma cells. The particles were surrounded by viroplasm (Fig. 3).

Amplification of PVCV DNA from infected petunia plants. The selected primers produced a distinctive band of expected size as predicted from the location of the primers on the PVCV genome (Richert-Poggeler and Shepherd, 1997). The product of the PCR, using the primer pairs $\mathrm{PV}-1$ and $\mathrm{PV}-2$, was a fragment of $\approx 730$-bp when total nucleic acids, either from a symptom-exhibiting petunia (cv. Chaplin) or from graft-inoculated $P$. hybrida, were used as a template (Fig. 4). Restriction digests of the amplified DNA with the restriction endonuclease BsmI yielded two fragments of the size predicted from the restriction map of the PVCV genome (data not shown).

We tested the applicability of the protocol for assaying PVCV in various petunia cultivars. The cvs. Big Spark, Pink Spark, Sweet Dream, Cascadias Yellow Eye, Bright Dream, and Cherie, expressing vein clearing symptoms, and $P$. hybrida graft-inoculated with PVCV, were tested. Healthy, nonsymptomatic, TMV- and CMV-, mechanically inoculated petunias were included as controls. Total nucleic acid was PCR amplified using the primer pairs PV-1 and PV-2 and subjected to electrophoresis. ADNA fragment of predicted size was visualized in agarose gels from all samples except the nonsymptomatic, TMVand CMV-infected petunias (results not shown). The authenticity of the amplified DNA fragment was confirmed by hybridization with an $\alpha^{32} \mathrm{P}$-dCTP-labeled PVCV DNA probe. The gel was blotted to Hybond $\mathrm{N}+$ membrane and hybridized with the virus-specific probe. The DNA probe reacted specifically with the amplified DNA fragments from all PCR-positive samples (Fig. 5). The amplified DNA fragments were the same size as that amplified from the symptom-exhibiting petunia cv.

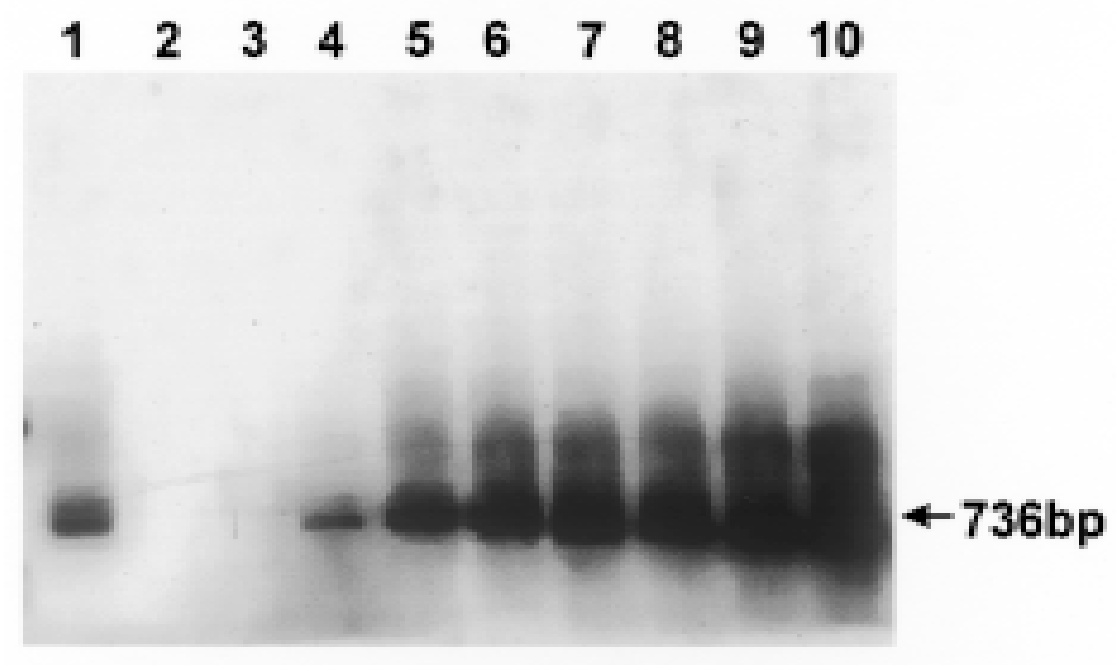

Fig. 5. Agarose gel electrophoresis of polymerase chain reaction (PCR) amplified petunia vein clearing virus (PVCV) DNA. Total nucleic acid was extracted and DNA was amplified using primers PV1 and PV2. The PCR products were collected, subjected to electrophoresis, blotted and hybridized with the PVCVspecific probe. Lane 1, total DNA from naturally infected Petunia cv. Chaplin; Lanes 2-4, total DNA from Petunia hybrida mechanically inoculated with tobacco mosaic virus, potato virus Y and graftinoculated with PVCV, respectively; lanes 5-10, total DNA from naturally infected 'Big Spark', 'Pink Spark', 'Sweet Dream', 'Cascadias Yellow Eye', 'Bright Dream', and 'Cherie', respectively. 
Chaplin. No bands were detected with DNA samples extracted from TMV- and CMV-infected petunias (Fig. 5, lanes 2 and 3), or in negative controls from which either primer or DNA was omitted (data not shown).

When total DNA extracted from infected plants was subjected to serial dilutions $\left(10^{-1}\right.$ to $10^{-8}$ ) in water, PVCV DNA was detected at a dilution of $10^{-6}$; however, no positive signal was obtained when further dilutions were tested (not shown). In a parallel experiment using ISEM and decoration with the specific PVCV antiserum, the virus was detected at a dilution of $10^{-3}$.

The high sensitivity of PCR compared with that of EM in the detection of PVCV in petunia makes it a powerful diagnostic method, and its role as a complementary technique for testing petunia mother plants used for in vitro propagation can be envisaged.

\section{Literature Cited}

Bellardi, M.G., C. Rubies-Aubies-Autonell, and V. Vicchi. 1996. Virus infections of Surfinia in Italy. Acta Hort. 432:88-94

Gera, A., N. Sikron, J. Cohen, and M. Zeidan. 2000. First report of petunia vein clearing virus in Israel. Plant Dis. 84:201
Hull, R. 1984. Caulimovirus group. CMI/AAB descriptions of plant viruses, no. 295.

Klinkowski, M. (Hrg.). 1968. Pflanzliche Virologie, Bd. II Die Virosen des europaischen Raumes, Teil 2 Akademie-Verlag Berlin $460 \mathrm{~S}$.

Lesemann, D.E. 1996. Viruses recently detected in vegetatively propagated petunia. Acta Hort. 432:88-92.

Lesemann, D.E. and R. Casper. 1973. Electron microscopy of petunia vein clearing virus, an isometric plant virus associated with specific inclusions in petunia cells. Phytopathology 63:1118-1124.

Lockhart, B.E.L. and D.E. Lesemann. 1997. Occurrence of petunia vein clearing virus in the U.S.A. Plant Dis. 82:262.

Milne, R.G. and D.E. Lesemann. 1984. Immunosorbent electron microscopy in plant virus studies. Methods in Virol. 8:85-101.

Milne, R.G. and E. Luisoni. 1975. Rapid highresolution immune electron microscopy of plant viruses. Virology 68:270-274.

Navot, N., M.Zeidan, E. Pichersky, D. Zamand, and H. Czosnek. 1992. Use of the polymerase reaction to amplify tomato yellow leaf curl virus DNA from infected plants and viruliferous whiteflies. Phytopathology 82:1199-1202.

Richert, K. 1992. Untersuchungen zur Charakterisierung des petunia vein-clearing virus (PVCV), ein samenubertragbares Pararetrovirus. PhD Diss., Univ. of Gottingen, Germany.
Richert-Poggeler, K.R. and R.J. Shepherd. 1997. Petunia vein clearing virus: A plant pararetrovirus with the core sequences for an integrase function. Virology 236:137-146.

Rogers, S.O. and A.J. Bendich. 1988. Extraction of DNA from plant tissues, p. A6:1-10. In: B.J. Stantoh and R.A. Schilperoort (eds.). Plant Molecular Biology Manual. Kluwer. Dordrecht, The Netherlands.

Rybicki,E.B. and F.L. Hughes. 1990. Detection and typing of maize streak virus and other distantly related geminiviruses of grasses by polymerase chain reaction amplification of a conserved viral sequence. J. Gen. Virol. 71:2519-2526.

Sambrook, J., E.F. Fritsch, and T. Maniatis. 1989. Molecular Cloning. A laboratory manual. 2nd ed. Cold Spring Harbor Laboratory. Cold Spring Harbor, N.Y.

Sikron, N., J. Cohen, S. Shoval, and A. Gera. 1995. Virus diseases in Petunia Phytoparasitica 23:273 (Abstr.).

Sikron, N., J. Cohen, S. Shoval, and A. Gera. 1999. Susceptibility of vegetatively propagated petunia to tobamovirus infection and its possible control. HortScience 34:292-293.

Weidner, E. 1994. Supertunias-more than just a petunia. Ohio Florist's Assn. Bul. 777:4-5.

Zeidan, M., J. Cohen, A. Watad, and A. Gera. 1998. Improved purification and molecular properties of Ornithogalum mosaic virus in Israel. Ann. Appl. Biol. 133:167-176. 